\title{
Serologic evidence of West Nile Virus infection in horses, Yucatan State, Mexico.*
}

\section{Contribuciones de la UADY a la Medicina}

María A. Loroño-Pino ${ }^{1,2}$, Bradley J. Blitvich ${ }^{1}$, José A. Farfán-Ale ${ }^{2}$, Fernando I. Puerto ${ }^{2}$, José M. Blanco², Nicole L. Marlenee ${ }^{1}$, Elsy P. Rosado-Paredes² ${ }^{2}$ Julian E. García-Rejón ${ }^{2}$, Duane J. Gubler ${ }^{3}$, Charles H. Calisher ${ }^{1}$, Barry J. Beaty ${ }^{1}$.

${ }^{1}$ Colorado State University, Fort Collins, Colorado, USA, ${ }^{2}$ Universidad Autonoma de Yucatan, Merida, Yucatan, Mexico, ${ }^{3}$ Centers for Disease Control and Prevention, Fort Collins, Colorado, USA.

\section{SUMMARY.}

Serum samples were obtained from 252 horses in the State of Yucatan, Mexico, from July to October 2002. Antibodies to West Nile virus were detected by epitopeblocking enzyme-linked immunosorbent assays in three $(1.2 \%)$ horses and confirmed by plaque reduction neutralization test. We report the first West Nile virus activity in the State of Yucatan.

(Rev Biomed 2003; 14:159-163)

Key words: West Nile Virus, zoonotic diseases, Yucatan Mexico.

\section{RESUMEN.}

Evidencia serológica de la infección por el Virus del Oeste del Nilo en caballos del estado de Yucatán, México.

Se obtuvieron muestras de suero de 252 caballos

\footnotetext{
* Reproduced from: Emerging Infectious Diseases 2003; 9:857-859.
}

en el estado de Yucatán, México, de julio a octubre de 2002. Se determinaron en ellos anticuerpos contra el virus del Oeste del Nilo a través del bloqueo de epítopes por ensayo inmunoenzimático. Se observó serorreactividad en $3(1.2 \%)$ caballos. Los resultados fueron confirmados a través de la reducción de neutralización de placas. Este es el primer reporte que demuestra la presencia del virus del Oeste del Nilo en el estado de Yucatán, México.

(Rev Biomed 2003; 14:159-163)

Palabras clave: Virus del Oeste del Nilo, enfermedades zoonóticas, Yucatán México.

West Nile virus (WNV) is a member of the Japanese encephalitis virus complex within the genus Flavivirus, family Flaviviridae (1). The virus is transmitted in natural cycles mainly between mosquitoes and birds, with humans and horses serving as incidental hosts (2). WNV was first isolated in 1937

Corresponding address: Revista Biomédica, Avenida Itzáes No. 490 x 59, C.P. 97000, Mérida, Yucatán, México.

Tel.: (999) 928-41-57 Fax: (999)923-61-20; E-mail: rebiomed@mucuy.uady.mx 


\section{MA Loroño-Pino, BJ Blitvich, JA Farfán-Ale, FI Puerto, JM Blanco, et al.}

from the blood of a febrile adult human in the West Nile District of Uganda (3). This virus has since been reported in Africa, the Middle East, Asia, southern Europe, Australia, and, more recently, North America $(4,5)$. The initial outbreak of WNV in North America was recognized in New York City in August 1999, with deaths reported in humans, horses, and numerous species of birds. Since then, the geographic distribution of WNV in North America has greatly increased. WNV activity has now been reported in 44 states and the District of Columbia in the United States and in 5 of the 10 Canadian provinces $(6,7)$.

In response to the incursion and rapid spread of WNV in North America, we established equine and avian infection surveillance in Yucatan State, Mexico, in March 2000. Yucatan State is a likely point of incursion of this virus into Latin America because this area is a principal landfall for many species of birds that migrate from the northeastern and midwestern United States (8).

To determine whether WNV had already reached this part of Mexico, we obtained blood samples from 252 domestic horses in 14 study sites from July to October 2002 (Table 1). The age distribution of the horses was 3 months to 25 years, and the mean age was 8.2 years. One hundred and fifty-one horses were male, and 101 were female. All study sites were on privately owned ranches, where the horses were primarily used to perform heavy labor and herd cattle. According to the owners, none of the horses had ever been outside the State of Yucatan. Furthermore, none of the horses had been vaccinated against WNV.

The climate and topography of the study sites are similar. The climate can be described as tropical. The average annual rainfall in each study site ranges from 600 to $1,100 \mathrm{~mm}$, and the average annual temperature is $26^{\circ} \mathrm{C}$. The average elevation is approximately $17 \mathrm{~m}$.

All serum samples were screened for antibodies to flaviviruses by hemagglutination inhibition (HI) assays and epitope-blocking enzyme-linked immunosorbent assays (ELISAs) at the Universidad Autonoma de Yucatan in Merida. HI assays were

\section{Revista Biomédica}

performed by using Saint Louis encephalitis virus (SLEV) antigen as previously described (9). This antigen recognizes cross-reactive $\mathrm{HI}$ antibodies to WNV and to other flaviviruses. To preclude nonspecific $\mathrm{HI}$ reactions, samples were treated with kaolin, then adsorbed with goose erythrocytes, according to standard methods (9). Epitope-blocking ELISAs were performed by using the flavivirus groupreactive monoclonal antibody (MAb), 6B6C-1, or the WNV-specific MAb, 3.1112G as previously described (10). The ability of the Mexican horse serum samples to block the binding of MAbs to WNV antigen was compared to the blocking ability of horse serum without antibody to WNV (Vector Laboratories, Burlingame, CA). Data were expressed as relative percentages, and inhibition values $330 \%$ were considered to indicate viral antibodies. Recent studies in this laboratory have shown that epitope-blocking ELISA provides a rapid and reliable serologic technique for the detection of WNV antibodies in various vertebrate species, including horses $(10,11)$.

Table 1

Study sites and numbers of horses sampled per site, State of Yucatan, Mexico.

\begin{tabular}{llc}
\hline Study site & $\begin{array}{l}\text { Global Positioning } \\
\text { System location }\end{array}$ & $\begin{array}{c}\text { No. (\%) of } \\
\text { horses bled }\end{array}$ \\
\hline Acanceh & $20^{\circ} 48^{\prime} 46^{\prime \prime} \mathrm{N}, 89^{\circ} 27^{\prime} 14^{\prime \prime} \mathrm{W}$ & $8(3.2)$ \\
Caucel & $21^{\circ} 00^{\prime} 53^{\prime \prime} \mathrm{N}, 89^{\circ} 42^{\prime} 25^{\prime \prime} \mathrm{W}$ & $1(0.4)$ \\
Hobonil & $20^{\circ} 00^{\prime} 54^{\prime \prime} \mathrm{N}, 89^{\circ} 01^{\prime} 15^{\prime \prime} \mathrm{W}$ & $26(10.3)$ \\
Hunucma & $21^{\circ} 00^{\prime} 55^{\prime \prime} \mathrm{N}, 89^{\circ} 52^{\prime} 28^{\prime \prime} \mathrm{W}$ & $7(2.8)$ \\
Mani & $20^{\circ} 23^{\prime} 11^{\prime \prime} \mathrm{N}, 89^{\circ} 23^{\prime} 37^{\prime \prime} \mathrm{W}$ & $1(0.4)$ \\
Merida & $20^{\circ} 58^{\prime} 04^{\prime \prime} \mathrm{N}, 89^{\circ} 37^{\prime} 18^{\prime \prime} \mathrm{W}$ & $63(25.0)$ \\
Molas & $20^{\circ} 48^{\prime} 57^{\prime \prime} \mathrm{N}, 89^{\circ} 37^{\prime} 55^{\prime \prime} \mathrm{W}$ & $5(2.0)$ \\
Progreso & $21^{\circ} 17^{\prime} 04^{\prime \prime} \mathrm{N}, 89^{\circ} 39^{\prime} 48^{\prime \prime} \mathrm{W}$ & $31(12.3)$ \\
Sierra Papacal $21^{\circ} 07^{\prime} 16^{\prime \prime} \mathrm{N}, 89^{\circ} 43^{\prime} 41^{\prime \prime} \mathrm{W}$ & $14(5.6)$ \\
Timucuy & $20^{\circ} 48^{\prime} 34^{\prime \prime} \mathrm{N}, 89^{\circ} 30^{\prime} 51^{\prime \prime} \mathrm{W}$ & $5(2.0)$ \\
Tixkokob & $21^{\circ} 00^{\prime} 08^{\prime \prime} \mathrm{N}, 89^{\circ} 23^{\prime} 37^{\prime \prime} \mathrm{W}$ & $15(6.0)$ \\
Tizimin & $21^{\circ} 08^{\prime} 32^{\prime \prime} \mathrm{N}, 88^{\circ} 09^{\prime} 03^{\prime \prime} \mathrm{W}$ & $49(19.4)$ \\
Uman & $20^{\circ} 49^{\prime} 38^{\prime \prime} \mathrm{N}, 89^{\circ} 41^{\prime} 08^{\prime \prime} \mathrm{W}$ & $26(10.3)$ \\
Xbec & $21^{\circ} 14^{\prime} 54^{\prime \prime} \mathrm{N}, 88^{\circ} 49^{\prime} 29^{\prime \prime} \mathrm{W}$ & $1(0.4)$ \\
Total & & \\
\hline
\end{tabular}

Six horses had evidence of flavivirus infection by HI assay or ELISA (Table 2). Serum samples from three of these horses (H-117, H-126, and H-252) 
West Nile Virus infection in horses, Yucatan Mexico.

Table 2

Summary of horses with HI assay or epitope-blocking ELISA antibodies to flaviviruses ${ }^{\mathrm{a}}$.

\begin{tabular}{|c|c|c|c|c|c|c|c|c|c|}
\hline \multirow{3}{*}{$\frac{\text { Horse }}{\mathrm{H}-60}$} & \multirow{3}{*}{$\begin{array}{l}\text { Sampling date } \\
\text { July 2, } 2002\end{array}$} & \multirow{3}{*}{$\begin{array}{l}\text { Study site } \\
\text { Merida }\end{array}$} & \multirow{3}{*}{$\frac{\text { Age }(y)}{8}$} & \multirow{3}{*}{$\begin{array}{l}\text { Sex } \\
\text { Male }\end{array}$} & \multirow{3}{*}{$\begin{array}{c}\text { Clinical symptoms } \\
\begin{array}{l}\text { Gastrointestinal } \\
\text { (recurrent colic) }\end{array}\end{array}$} & \multirow{3}{*}{$\begin{array}{l}\text { HI assay } \\
\text { Outcome }\end{array}$} & \multirow{3}{*}{$\frac{\text { titer }}{10}$} & \multicolumn{2}{|c|}{$\begin{array}{l}\% \text { inhibition by } \\
\text { blocking ELISA }\end{array}$} \\
\hline & & & & & & & & $3.1112 \mathrm{G}^{\mathrm{c}}$ & $6 \mathrm{~B} 6 \mathrm{C}-1^{\mathrm{d}}$ \\
\hline & & & & & & & & 0 & 59 \\
\hline H-117 & July 5, 2002 & Tizimin & 7 & Male & None & Survived & 10 & 84 & 93 \\
\hline H-126 & July 5, 2002 & Tizimin & 2 & Male & None & Survived & 40 & 87 & 93 \\
\hline H-134 & July 5, 2002 & Tizimin & 3 & Female & None & Survived & 10 & 11 & 0 \\
\hline H-141 & July 5, 2002 & Tizimin & 10 & Male & None & Survived & 80 & 5 & 47 \\
\hline $\mathrm{H}-252$ & Oct. 15,2002 & Caucel & 3 & Male & $\begin{array}{l}\text { Neurologic and } \\
\text { muscular symptoms }\end{array}$ & Euthanized & 20 & 64 & 25 \\
\hline
\end{tabular}

${ }^{a} \mathrm{HI}$, hemagglutination-inhibition; ELISA, enzyme-linked immunosorbent assay.

'Inhibition values $>30 \%$ are considered significant.

${ }^{c} \mathrm{MAb}$ 3.1112G is WNV-specific.

${ }^{\mathrm{d}} \mathrm{MAb} 6 \mathrm{~B} 6 \mathrm{C}-1$ is flavivirus group-reactive.

were positive in the ELISA that used the WNVspecific MAb. H-117 (7- year-old stallion) and $\mathrm{H}$ 126 (2-year-old stallion) were both sampled at the Tizimin study site. Neither horse showed signs of illness at the time of serum collection or during the 7 months that followed. Furthermore, neither horse had a history of WNV-like illness. H-252 was a 3-year-old stallion from Caucel that exhibited neurologic and muscular symptoms at the time of sampling; it was euthanized several hours later. We were not able to obtain tissue specimens from this horse postmortem. Of the 252 horses sampled, the only other horse to exhibit signs of clinical illness was H-60, which had signs consistent with gastrointestinal illness.

Serum samples positive for flavivirus antibodies by HI assay or ELISA were tested by plaque reduction neutralization assay (PRNT) to identify the infecting virus. PRNTs were conducted in the BSL-3 facilities at Colorado State University. Serum sample results shown to be negative by HI assay and ELISA were not tested. PRNTs were done by using WNV (strain NY99-35261-11), SLEV (strain TBH-28), Ilhéus virus (ILHV, original strain), and Bussuquara virus (BSQV, strain BeAn-4073). Virus stocks were obtained from the World Health Organization Center for Arbovirus Reference and Research, maintained at the Centers for Disease Control and Prevention,
Division of Vector-Borne Infectious Diseases, Fort Collins, $\mathrm{CO}$. We tested serum samples for neutralizing antibodies to SLEV because the virus is enzootic in the Americas and because antibodies to WNV and SLEV often cross-react. Furthermore, horses are susceptible to natural SLEV infections, although clinical manifestations have not been reported (12). ILHV and BSQV are also present in the Americas, although neither virus is known to naturally infect horses (2). PRNTs were performed by using Vero cells. Serum samples were tested by using a starting dilution of 1:20. Titers were expressed as the reciprocal of serum dilutions yielding ${ }^{3} 90 \%$ reduction in the number of plaques $\left(\mathrm{PRNT}_{90}\right.$ ).

Neutralizing antibodies to WNV were detected in three horses (Table 3). The PRNT-positive horses were $\mathrm{H}-117, \mathrm{H}-126$, and $\mathrm{H}-252$, which exhibited $\mathrm{PRNT}_{90}$ antibody titers of 320, ${ }^{3} 2,560$, and 160, respectively. The SLEV, ILHV, and BSQV antibody titers of the three horses were all < 20. Therefore, we considered H-117, H-126, and H-252 to be seropositive for WNV because the $\mathrm{PRNT}_{90}$ antibody titers for WNV were more than fourfold higher than the other flaviviruses tested. Overall, the PRNT and ELISA data were in concordance; all serum samples that contained neutralizing antibodies to $\mathrm{WNV}$ were positive in the assay that used MAb 3.1112G (Tables 


\section{MA Loroño-Pino, BJ Blitvich, JA Farfán-Ale, FI Puerto, JM Blanco, et al.}

2 and 3 ). However, $\mathrm{H}-252$ was negative in the assay that used MAb 6B6C-1, although the percent inhibition value was close to the diagnostic criterion. The three other horses (H-60, H-134, and H-141) that were positive for flavivirus antibodies by HI assay or ELISA did not have neutralizing antibodies to WNV. H-60 had a low SLEV PRNT ${ }_{90}$ titer, suggesting it had been infected with SLEV or a closely related virus. H-134 exhibited a HI titer of 10 but was negative by the other serologic tests, suggesting that the $\mathrm{HI}$ antigen had reacted nonspecifically. $\mathrm{H}-141$ was positive by $\mathrm{HI}$ assay and ELISA but had no neutralizing antibodies to any flavivirus tested; thus, the identity of the infecting virus was not determined.

Table 3

Neutralizing antibody titers to West Nile, Saint Louis encephalitis, Ilhéus, and Bussuquara viruses in serum samples from six horses ${ }^{\mathrm{a}}$.

\begin{tabular}{lcccc}
\hline & \multicolumn{4}{c}{ PRNT $_{90}$ titer } \\
\cline { 2 - 5 } Horse & WNV & SLEV & ILHV & BSQV \\
\hline H-60 & $-^{\mathrm{b}}$ & $20^{\mathrm{c}}$ & $-^{\mathrm{b}}$ & - \\
H-117 & 320 & - & $-^{\mathrm{b}}$ & - \\
H-126 & $>2,560$ & $-^{\mathrm{b}}$ & - & - \\
H-134 & - & - & - & - \\
H-141 & - & - & - & - \\
H-252 & 160 & - & - & - \\
\hline
\end{tabular}

${ }^{a}$ WNV, West Nile virus; SLEV, Saint Louis encephalitis virus; ILHV, Ilhéus virus; BSQV, Bussuquara virus; PRNT, plaque reduction neutralization test;,$-<20$.

${ }^{\mathrm{b}} \mathrm{PRNT}_{80}$ titer: 20.

'PRNT 80 titer: 40.

We obtained serologic evidence for antibodies to WNV in Yucatan State, Mexico. The mode of entry of this virus into Yucatan State is not known; however, the virus may have been brought in by birds migrating from the north.

We have also detected antibodies to WNV in certain species of migratory birds, which supports this hypothesis. Data from the avian surveillance studies conducted in Yucatan State will be described separately (J.A. Farfán- Ale, unpub. data). We plan to isolate and amplify viral sequences from migratory and resident birds, as well as from specimens from other seropositive animals, to determine the origin of the WNV strain in Yucatan State. We also provide serologic evidence for WNV infection in horses in Coahuila State (13). These two reports provide the first published evidence of WNV activity in horses in Mexico. Neutralizing antibodies to WNV have also been detected in a bovine in Chiapas, Mexico, in mid2001, indicating that the animal had been infected with WNV or a closely related virus (14). WNV may become endemic in this country, which demonstrates the importance for continued WNV surveillance in Mexico, and elsewhere in the south.

\section{ACKNOWLEDGMENTS.}

We thank Eduardo Sierra-Lira and Edwin J. GutierrezRuiz for collecting the serum specimens and Luis F. FloresFlores and Richard Bowen for technical assistance. This study was supported by grant U50 CCU820510 from the Centers for Disease Control and Prevention and in part by grant AI45430 from the National Institutes of Health.

\section{REFERENCES.}

1. Heinz FX, Collett MS, Purcell RH, Gould EA, Howard CR, Houghton M, et al. Family Flaviviridae. Virus taxonomy. In: Van Regenmortel CM, Fauquet CM, Bishop DHL, Carstens E, Estes MK, Lemon S, et al., editors. 7th report of the International Committee for the Taxonomy of Viruses. San Diego (CA): Academic Press; 2000. p. 859-78.

2. Burke DS, Monath TP. Flaviviruses. In: Knipe DM, Howley PM, editors. Fields virology. 4th ed. Philadelphia (PA): Lippincott Williams and Wilkins; 2001. p. 1043-126.

3. Smithburn KC, Hughes TP, Burke AW, Paul JH. A neurotropic virus isolated from the blood of a native of Uganda. Am J Trop Med Hyg 1940; 20:471-92.

4. Campbell GL, Marfin AA, Lanciotti RS, Gubler DJ. West Nile virus. Lancet Infect Dis 2002; 2:519-29.

5. Roehrig JT, Layton M, Smith P, Campbell GL, Nasci R, Lanciotti RS. The emergence of West Nile virus in North America: ecology, epidemiology, and surveillance. Curr Top Microbiol Immunol 2002; 267:223-40.

6. Centers for Disease Control and Prevention. Provisional surveillance summary of the West Nile Virus epidemicUnited States, January-November 2002. MMWR Morb Mortal Wkly Rep 2002; 51:1129-33.

\section{Revista Biomédica}


7. Health Canada. Population and Public Health Branch WNV surveillance updates, December 4, 2002. Available from: URL: http://www.hc-sc.gc.ca/pphb-dgspsp/wnv-vwn/ mon_e.html\#sitrep

8. Howell SNG, Webb S. A guide to the birds of Mexico and northern Central America. Oxford: Oxford University Press; 1995.

9. Calisher CH, Beaty BJ, Chandler LJ. Arboviruses. In: Lennette E, editor. Laboratory diagnosis of viral infections. 3rd ed. New York: Marcel Dekker Inc; 1999. p. 305-32.

10. Blitvich BJ, Marlenee NL, Hall RA, Calisher CH, Bowen RA, Roehrig JT, et al. Epitope-blocking enzyme-linked immunosorbent assays for the detection of serum antibodies to West Nile virus in multiple avian species. J Clin Microbiol 2003; 41:1041-7.

11. Blitvich BJ, Bowen RA, Marlenee NL, Hall RA, Bunning ML, Beaty BJ. Epitope-blocking enzyme-linked immunosorbent assays for the detection of West Nile virus antibodies in domestic mammals. J Clin Microbiol. 2003; 41:2676-9.

12. Tsai TF, Mitchell CJ. St. Louis encephalitis. In: Monath TP, editor. Vol. IV, The arboviruses: epidemiology and ecology. Boca Raton (FL): CRC Press; 1988. p. 113-43.

13. Blitvich BJ, Fernandez-Salas I, Contreras-Cordero JF, Marlenee NL, Gonzalez-Rojas JI, Komar N, et al. Serologic evidence of West Nile virus infection in horses, Coahuila State, Mexico. Emerg Infect Dis 2003; 9:853-6.

14. Ulloa A, Langevin SA, Mendez-Sanchez JD, ArredondoJimenez JI, Raetz JL, Powers AM, et al. Serologic survey of domestic animals for zoonotic arbovirus infections in the Lacandón Forest region of Chiapas, Mexico. Vector Borne Zoonotic Dis. In press 2003. 